\title{
Multiple morphological abnormalities in a blue shark Prionace glauca (Linnaeus, 1758) embryo from the Peruvian coast, southeast Pacific
}

\author{
Keny Kanagusuku ${ }^{1}$, Miguel Romero ${ }^{2}$ \& Sergio Ramírez-Amaro ${ }^{3}$ \\ ${ }^{1}$ Facultad de Ciencias Veterinarias y Biológicas, Universidad Científica del Sur, Lima, Perú \\ ${ }^{2}$ Área Funcional de Investigaciones en Biodiversidad, Instituto del Mar del Perú, Callao, Perú \\ ${ }^{3}$ Instituto Español de Oceanografía, Centro Oceanográfico de les Balears, Palma de Mallorca, España \\ Corresponding author: Miguel Romero (mromero@imarpe.gob.pe)
}

\begin{abstract}
This study reports for the first time a case of multiple morphological abnormalities in a blue shark Prionace glauca embryo collected on the Peruvian coast, southeast Pacific. External exploration and radiograph picture showed duplicated parts in the cephalic region (mouths and eye sockets) and trunk anomalies (thoracic lordosis and rolled caudal fin). The duplicate face parts in a single head seen in the embryo, suggest a diprosopia anomaly.
\end{abstract}

Keywords: Prionace glauca; blue shark; abnormalities; deformity; malformation; teratology; Peru

Several morphological abnormalities have been reported in sharks (Subclass: Selachii) in different marine ecoregions around the world. This reports include albinism (e.g., Clark, 2002; Saïdi et al., 2006; Bottaro et al., 2008; Escobar-Sánchez et al., 2014), bicephaly (e.g., Galván-Magaña et al., 2011; Wagner et al., 2013), diprosopia (e.g., Mancini et al., 2006; HeviaHormazábal et al., 2011; Driggers et al., 2012), deformities in axial skeleton (e.g., Pastore \& Prato, 1989; Heupel et al., 1999; Mancini et al., 2006), mummification (e.g., Rosa-Molinar et al., 1983; Sandoval-Castillo \& Villavicencio-Garay-Zar, 2008) and even cyclopia (Bejarano-Álvarez \& GalvánMagaña, 2013). Blue shark (Prionace glauca) is the shark species with the highest number of anomalies reported, which have been described by different authors (e.g., Goto et al., 1981; Mancini et al., 2006; Galván-Magaña et al., 2011; Hevia-Hormazábal et al., 2011; Bejarano-Álvarez et al., 2013; Ehemann et al., 2016; Rodríguez-Romero et al., 2018; Ramírez-Amaro et al., 2019).

The blue shark is one of the most abundant shark species in temperate, subtropical and tropical seas (Fischer et al., 1995; Nakano \& Stevens, 2008; Castro, 2010). It is a pelagic species mainly distributed from the epipelagic zone to depths of about $350 \mathrm{~m}$, even reached 1,000 m (Da Silva et al., 2010; Campana et al.,
2011). This shark is placental viviparous, producing litters averaging about 35 pups after a gestation period of 9-12 months and the size at birth is between 350 and $500 \mathrm{~mm}$ total length (Fischer et al., 1995; Camhi et al., 1998; Nakano \& Stevens, 2008; Castro, 2010; IMARPE, 2015). This report describes the first record of multiple abnormalities in an embryo of $P$. glauca collected on the Peruvian coast.

In September 1995, a pregnant P. glauca female was caught product of artisanal fishery in Puerto Nuevo, Piura, Peru $\left(27^{\circ} 06^{\prime} 23^{\prime}\right.$ W, $05^{\circ} 05^{\prime} 28^{\prime \prime}$ ) $)$ with an unusual embryo with multiple abnormalities in the region of the head and trunk. The information about weight and the total length of the female blue shark could not be obtained. The embryo was preserved in a $10 \%$ formaldehyde solution, which later was changed to $70 \%$ ethylic alcohol and stored in the Ichthyologic Scientific Collection from the Peruvian Marine Research Institute with catalog number: IMARPE 01000148. For species identification, we reviewed studies of Chirichigno \& Vélez (1998) and Romero et al. (2015). The specimen was measured, photographed and radiographed using Examion CR Vita 25 equipment.

The anomalous embryo was a female $P$. glauca with a total length of $25.2 \mathrm{~cm}$ and weight of $104.27 \mathrm{~g}$. The embryo presented head with a pair of nostrils with two dorsal and pectoral fins, one anal fin, and one caudal

Corresponding editor: Leonardo Abitia 


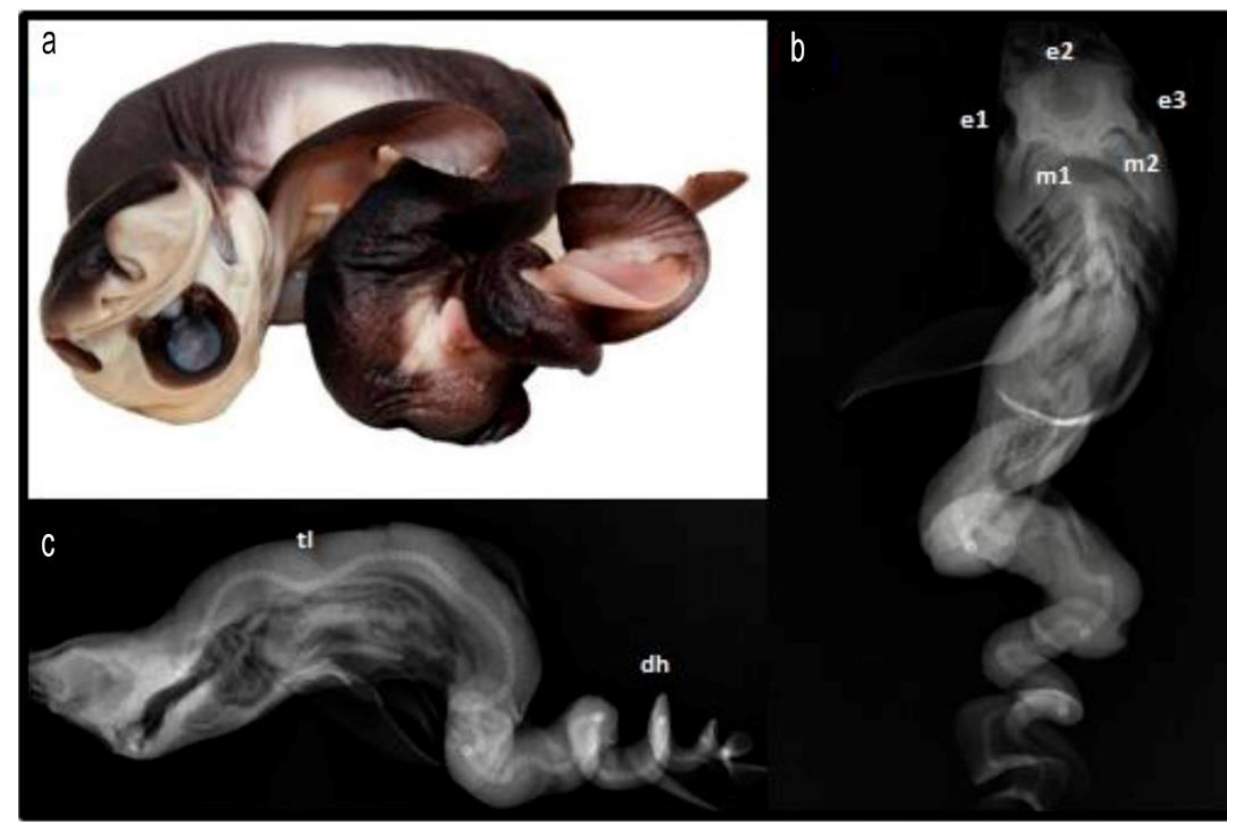

Figure 1. a) Anomalous embryo of the blue shark, Prionace glauca from Puerto Nuevo, Piura, Peru (southeast Pacific) with multiple morphological anomalies, b) ventral view of X-ray plate showing the three eyes (e1, e2 and e3) and two mouths $(\mathrm{m} 1$ and $\mathrm{m} 2), \mathrm{c})$ dorsal view of X-ray plate showing a thoracic lordosis (tl) and dextrorotatory helical (dh).

fin. However, in the cephalic region, duplicated structures were observed: two mouths opened laterally, converging in a common pharyngeal duct and three ocular sockets that could correspond to the eyes (Fig. 1). The embryo showed an axial skeleton with thoracic lordosis, defines by an exaggerated curvature of the vertebral column in the lumbar area. Likewise, at the posterior end of the trunk was rolled in an anticlockwise direction from pelvic to caudal fin (named "screwshaped"), as it can be observed in radiograph picture (Fig. 1).

In southeast Pacific, reports of morphological anomalies in sharks remain rare. Two more cases have been reported, one of them in a $P$. glauca embryo collected off the Chilean coast (Hevia-Hormazábal et al., 2011) and the other one in a Carcharhinus porosus embryo from Colombian coast (Muñoz-Osorio et al., 2013). Here, we reported the first record of multiple abnormalities in a P. glauca embryo collected off the Peruvian coast. This embryo showed duplicate face parts (mouth and eyes) in a single head, which indicates a morphological anomaly named diprosopia (Biasibetti et al., 2011). The additional middle eye socket could indicate an early diprosopia stage, in which eyes are still developing. In sharks, this anomaly is commonly confused with bicephaly (Sans-Coma et al., 2016). This last is related to conjoined twins with two entirely separated heads on one trunk (Bondeson, 2001). Diprosopia could be the result of several development problems such as duplications parts derived from the branchial arch, complex bifurcation of the notochord, duplications of olfactory placodes, or neural crest (Maisels, 1981; Carles et al., 1995; Sans-Coma et al., 2016).

Furthermore, our specimen showed thoracic lordosis and helical torsion in the trunk area, which has been previously recorded for blue shark (Mancini et al., 2006; Hevia-Hormazábal et al., 2011; Lamarca et al., 2017; Pastén-Marabio et al., 2018). These skeletal abnormalities could be related to parasitic infections, injuries, malnutrition, vitamin $\mathrm{C}$ deficiency or congenital diseases (Mahajan \& Agrawal, 1979; Wimberger, 1993; Heupel et al., 1999). On the other hand, it is known that morphological abnormalities registered in blue shark may be related to high embryo production (Mancini et al., 2006), varying from 28 to 54 embryos per litter, reaching a maximum record of 135 embryos (Compagno, 1984; Castro et al., 1999). In this species, uterus reduction due to a high number of embryos generates abnormal embryo development (Mancini et al., 2006; Ramírez-Amaro et al., 2019).

Another factor that can be affecting the malformation presence is environmental degradation or pollution (Goto et al., 1981; Ferreira et al., 2002; Rosa et al., 2004; Mancini et al., 2006). In this context, some studies have been reported presence of high levels of heavy metals (e.g., Hg) (Barrera-García et al., 2012; Rodríguez-Romero et al., 2018) and genetic alterations 
related with initial stages of development (Mancini et al., 2006; Rodríguez-Romero et al., 2018). Although the lack of information about the causes of anomalies, an explanation for some individual reported in this study who did not survive after birth, could be related with difficulties in swimming, feeding and avoiding predators in these individuals (Mancini et al., 2006; Rodríguez-Romero et al., 2018).

Current and previous reports about morphological anomalies shed light on the possible causes of these deformations in sharks (Ramírez-Amaro et al., 2019), but more studies about this topic are needed, especially in commercial relevant species.

\section{ACKNOWLEDGMENTS}

Thanks to J.L. Castillo-Géniz for supplying literature, A. Rubio Valdivieso's Veterinary Clinic for allowing us to take the X-ray, the fishermen who collected the specimen and M. Vitor for English review. Especial thanks to P. Dufflocq for his comments and revision to the final manuscript. Sergio Ramírez-Amaro is funded by a post-doctoral contract from the regional government of the Balearic Islands, co-funded by the European Social Fund 2014-2020.

\section{REFERENCES}

Barrera-García，A., O’Hara，T., Galván-Magaña， F., Méndez-Rodríguez, L.C., Castellini, J.M. \& ZentenoSavín, T. 2012. Oxidative stress indicators and trace elements in the blue shark (Prionace glauca) off the east coast of the Mexican Pacific Ocean. Comparative Biochemistry and Physiology Part C: Toxicology \& Pharmacology, 156(2): 59-66. doi: 10.1016/j.cbpc. 2012.04.003

Bejarano-Álvarez, O.M. \& Galván-Magaña, F. 2013. First report of an embryonic dusky shark (Carcharhinus obscurus) with cyclopia and other abnormalities. Marine Biodiversity Records, 6. doi: 10.1017/s175 5267212001236

Biasibetti, E., D'Angelo, A., Bellino, C., Gay, L., Gianella, P. \& Capucchio, M.T. 2011. Diprosopia/ Dicephalia in calves in northern Italy: clinical and aetio-pathological features. Anatomia, Histologia, Embryologia, 40(6): 433-440. doi: 10.1111/j.14390264.2011. 01093.x

Bondeson, J. 2001. Dicephalus conjoined twins: a historical review with emphasis on viability. Journal of Pediatric Surgery, 36(9): 1435-1444. doi: 10.1053/ jpsu.2001.26393

Bottaro, M., Ferrando, S., Gallus, L., Girosi, L. \& Vacchi, M. 2008. First record of albinism in the deep-water shark Dalatias licha. Marine Biodiversity Records, 1: e10. doi: $10.1017 /$ S1755267205001156

Camhi, M., Fowler, S.L., Musick, J.A., Bräutigam, A. \& Fordham, S.V. 1998. Sharks and their relative's ecology and conservation. Occasional Paper of the IUCN Species Survival Commission $\mathrm{N}^{\circ}$ 20. IUCN Publications Services Unit, Cambridge, 39 pp.

Campana, S.E., Dorey, A., Fowler, M., Joyce, W., Wang, Z., Wright, D. \& Yashayaev, I. 2011. Migration pathways, behavioral thermoregulation and overwintering grounds of blue sharks in the Northwest Atlantic. Plos One, 6(2): e16854. doi: 10.1371/journal. pone. 0016854

Carles, D., Weichhold, W., Alberti, E. M., Léger, F., Pigeau, F. \& Horovitz, J. 1995. Diprosopia revisited in light of the recognized role of neural crest cells in facial development. Journal of Craniofacial Genetics and Developmental Biology, 15: 90-97.

Castro, J.I. 2010. The sharks of North America. Oxford University Press, Oxford.

Castro, J.I., Woodley, C.M. \& Brudek, R.L. 1999. A preliminary evaluation of the status of shark species. FAO Fisheries Technical Paper, 380. FAO, Rome.

Chirichigno, N. \& Vélez, J. 1998. Clave para identificar los peces marinos del Perú. Publicación especial. Instituto del Mar del Perú, Lima, 496 pp.

Clark, S. 2002. First report of albinism in the whitespotted bamboo shark, Chiloscyllium plagiosum (Orectolobiformes: Hemiscyllidae), with a review of reported color aberrations in elasmobranchs. Zoo Biology, 21(6): 519-524. doi: 10.1002/zoo. 10068

Compagno, L.J. 1984. Sharks of the world: an annotated and illustrated catalog of shark species known to date. FAO Fisheries Synopsis, 125: 249 pp.

Da Silva, C., Kerwath, S.E., Wilke, C.G., Meyer, M. \& Lamberth, S.J. 2010. First documented southern transatlantic migration of a blue shark Prionace glauca tagged off South Africa. African Journal of Marine Science, 32(3): 639-642. doi: 10.2989/1814232X. 2010.540777

Driggers, W.B., Hannan, K.M., Hoffmayer, E.R. \& Jensen, J. 2012. Abnormal blacktip shark, Carcharhinus limbatus, embryo from the northern Gulf of Mexico. Journal of Applied Ichthyology, 28(5): 827828. doi: 10.1111/j.1439-0426.2011.01924.x

Ehemann, N., Marín-Sanz, J. \& Barany-González, M. 2016. Two cases of two-head shark embryos, small eye smooth-hound Mustelus higmani, and the blue shark Prionace glauca. Boletín de Investigaciones Marinas y Costeras, 45(1): 149-153.

Escobar-Sánchez, O., Moreno-Sánchez, X.G., AguilarCruz, C.A. \& Abitia-Cárdenas, L.A. 2014. First case 
of synophthalmia and albinism in the Pacific angel shark Squatina californica. Journal of Fish Biology, 85(2): 494-501. doi: 10.1111/jfb. 12412

Ferreira, L.A., Ferreira, T.G.A. \& Amorim, A.F. 2002. Embryo anomaly of blue shark, Prionace glauca (Linnaeus, 1758) Carcharhinidae, Carcharhiniformes. III Reunião da Sociedade Brasileira para Estudo em Elasmobrãnquios (SBEEL). Caderno de Resumos, pp. 38-39.

Fischer, W., Krupp, F., Schneider, W., Sommer, C., Carpenter, K.E. \& Niem, V.H. 1995. Guía FAO para la identificación de especies para los fines de la pesca: Pacífico centro-oriental. Vertebrados. FAO, Rome, pp. 647-1813.

Galván-Magaña, F., Escobar-Sánchez, O. \& CarreraFernández, M. 2011. Embryonic bicephaly in the blue shark, Prionace glauca, from the Mexican Pacific Ocean. Marine Biodiversity Records, 4. doi: 10.1017/S1755267210001120

Goto, M., Taniuchi, T., Kuga, N. \& Iwata, M. 1981. Four dicephalous specimens of the blue shark, Prionace glauca, from Japan. Japanese Journal of Ichthyology, 28(2): 157-165. doi: 10.11369/jji1950.28.157

Heupel, M.R., Simpfendorfer, C.A. \& Bennett, M.B. 1999. Skeletal deformities in elasmobranchs from Australian waters. Journal of Fish Biology, 54(5): 1111-1115. doi:10.1111/j.1095-8649.1999.tb00861.x

Hevia-Hormazábal, V., Pastén-Marambio, V. \& Vega, A. 2011. Registro de un monstruo diprósopo de tiburón azul (Prionace glauca) en Chile. International Journal of Morphology, 29(2): 509-513. doi: /10.4067/S071795022011000200034

Instituto del Mar del Perú (IMARPE). 2015. Guía para la determinación de tiburones de importancia comercial en el Perú. IMARPE, Serie de Divulgación Científica, 1(2): 80 pp.

Lamarca, F., Ribeiro, N., Galheigo, F. \& Vianna, M. 2017. The first record of Diprosopus tetrophthalmus in the South Atlantic Ocean: the case of Prionace glauca (Elasmobranchii: Carcharhiniformes: Carcharhinidae) in Brazil. Acta Ichthyologica et Piscatoria, 47(4): 385389.

Mahajan, C.L. \& Agrawal, N.K. 1979. Vitamin C deficiency in Channa punctatus Bloch. Journal of Fish Biology, 15(5): 613-622.

Maisels, D.O. 1981. Reduplication of the mouth and mandible. Journal of Plastic, Reconstructive \& Aesthetic Surgery, 34(1): 23-25.

Mancini, P.L., Casas, A.L. \& Amorim, A.F. 2006. Morphological abnormalities in a blue shark Prionace glauca (Chondrichthyes: Carcharhinidae) fetus from southern Brazil. Journal of Fish Biology, 69(6): 18811884. doi: 10.1111/j.1095-8649.2006.01238.x

Muñoz-Osorio, L.A., Mejía-Falla, P.A. \& Navia, A.F. 2013. First record of a bicephalic embryo of smalltail shark Carcharhinus porosus. Journal of Fish Biology, 82(5): 1753-1757. doi: $10.1111 / \mathrm{jfb} .12102$

Nakano, H. \& Stevens, J.D. 2008. The biology and ecology of the blue shark, Prionace glauca. In: Camhi, M.D., Pikitch, E.K. \& Babcock, E.A. (Eds.). Sharks of the open ocean: biology, fisheries, and conservation. Blackwell Publishing, Oxford, pp. 140-151.

Pastén-Marambio, V., Hevia-Hormazábal, V., Acuña, E. \& Vega, J.A. 2018. A case of tetrophthalmia with unilateral synophthalmia in an unborn fetus of blue shark Prionace glauca (Carcharhiniformes, Carcharhinidae). Revista de Biología Marina y Oceanografía, 53(S1): 25-30. doi: 10.22370/rbmo.2018.53.0.1251

Pastore, M. \& Prato, E. 1989. A teratologic case in a shark. Thalassia Salentina, 19: 87-92.

Ramírez-Amaro S., Fernández-Peralta L., Serna, F. \& Puerto, M.A. 2019. Abnormalities in two shark species, the blue shark Prionace glauca and the school shark Galeorhinus galeus (Elasmobranchii: Carcharhiniformes), from the Canary Islands, eastern tropical Atlantic. Acta Ichthyologica et Piscatoria, 49(3): 295303.

Rodríguez-Romero, J., Simeón-de la Cruz, A., OchoaDíaz, M.R. \& Monsalvo-Spencer, P. 2018. New report of malformations in blue shark embryos (Prionace glauca) from the western coast of Baja California Sur, Mexico. Journal of the Marine Biological Association of the United Kingdom, 99(2): 1-6. doi: 10.1017/s002 5315418000127

Romero, M., Alcántara, P. \& Verde, K. 2015. Guía de campo para la determinación de tiburones en la pesca artesanal del Perú. Instituto del Mar del Perú, Lima, 15 pp.

Rosa, R.S., Mariano, E.F. \& Sampaio, C.L.S. 2004. Máformação em Rhinobatus percellens Jord \& Evern, 1896; Rhinobatidae na Baia de Todos os Santos, BA. Reunião da Sociedade Brasileira para Estudo em Elasmobrânquios (SBEEL). Caderno de Resumos, pp. 165-166.

Rosa-Molinar, E., Williams, C.S. \& Collard, S. 1983. Fetal mummification in the sandbar shark, Carcharhinus plumbeus (Nardo, 1827). Journal of Wildlife Diseases, 19(2): 156-158.

Saidi, B., Bradai, M.N., Marouani, S., Guelorget, O. \& Capape, C. 2006. Atypical characteristics of an albino embryo of Carcharhinus plumbeus (Chondrichthyes: Carcharhinidae) from the Gulf of Gabès (southern 
Tunisia, central Mediterranean). Acta Adriatica, 47(2): 167-174.

Sandoval-Castillo, J. \& Villavicencio-Garayzar, C. 2008. Fetal mummification in silky shark (Carcharhinus falciformis) from the Gulf of California, Mexico. Brazilian Archives of Biology and Technology, 51(3): 551-554. doi: 10.1590/S1516-89132008000300015

Sans-Coma, V., Rodríguez, C., López-Unzu, M.A., Lorenzale, M., Fernández, B., Vida, L. \& Durán, A.C. 2016. Dicephalous v. diprosopus sharks: record of a two-headed embryo of Galeus atlanticus and review of the literature. Journal of Fish Biology, 90(1): 283293. doi: $10.1111 / \mathrm{jfb} .13175$

Received: 3 April 2019; Accepted: 12 August 2019
Wagner, C.M., Rice, P.H. \& Pease, A.P. 2013. First record of dicephalia in a bull shark Carcharhinus leucas (Chondrichthyes: Carcharhinidae) fetus from the Gulf of Mexico, U.S.A. Journal of Fish Biology, 82(4): 1419-1422. doi: 10.1111/jfb. 12064

Wimberger, P.H. 1993. Effects of vitamin C deficiency on body shape and skull osteology in Geophagus brasiliensis: implications for interpretations of morphological plasticity. Copeia, 1993(2): 343. doi: $10.2307 / 1447135$ 